\title{
Política, silenciamento e representações: os setores populares na historiografia sobre o regime stronista
}

\section{Politics, silencing and representations: the popular sectors in the historiography of the stronista regime}

\author{
Paulo Alves Pereira Júnior
}

\begin{abstract}
Resumo
A historiografia sobre os modos de resistência às ditaduras cívico-militares na América Latina destaca, principalmente, as ações dos grupos "intelectualizados" da sociedade e dos trabalhadores urbano-industriais, organizados em sindicatos e partidos políticos. Já muitos intelectuais marxistas que desenvolvem estudos sobre esses governos autoritários priorizam como sujeito histórico o proletariado. Assim, como explicar o caso de resistências a regimes militares existentes em países agroexportadores, como o Paraguai? Nesse caso, o conceito de proletariado se manifestaria insuficiente, pois não conseguiria explicar as ações de parcelas expressivas da sociedade. Assim, utilizaremos a noção de setores populares, entendida como a constituição de trabalhadores que não estejam necessariamente inseridos no processo produtivo urbano-industrial. Tendo em vista essas questões, o presente trabalho identificará as representações sobre os setores populares presentes nas produções historiográficas que abordam o período marcado pela ditadura cívico-militar do General Alfredo Stroessner no Paraguai.
\end{abstract}

Palavras-chave: Paraguai; stronismo; produção historiográfica; setores populares.

\begin{abstract}
The historiography about the modes of resistance to civil-military dictatorship in Latin America highlights mainly the actions of "intellectualized" groups of society and of urban-industrial workers organized in trade unions and political parties. Already many Marxists intellectuals developed studies about this authoritarian governments where they chosen proletariat as main historical subject. So, how to explain the case of resistance to existing military regimes in agroexporting countries such as Paraguay? In this case, the concept of proletariat is insufficient, because it cannot explain the expressive action of groups in Paraguayan society. Thus, we use the concept of popular sectors, understood as the establishment of employees who are not necessarily included in the urban-industrial production process. In view of these issues, this study will identify the representations of popular sectors present in historiographies that address the period marked by civic-military dictatorship of General Alfredo Stroessner in Paraguay.
\end{abstract}

Keywords: Paraguay; stronismo; historiographic production; popular sectors.

\footnotetext{
${ }^{1}$ Bacharel em História - América Latina pela Universidade Federal da Integração Latino-Americana (UNILA). Mestrando em História pela Universidade Estadual Paulista (UNESP). E-mail: paulopereira_pf@ hotmail.com.
}

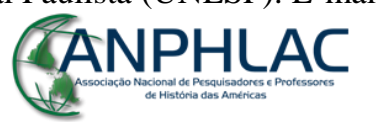

Revista Eletrônica da ANPHLAC, ISSN 1679-1061, №. 18, p. 23-56, jan./jul. 2015.

http://revista.anphlac.org.br/ 
Artigo recebido em: 25 de janeiro de 2015

Artigo aprovado para publicação em: 20 de abril de 2015

\section{Introdução}

As produções sobre as formas de resistência às ditaduras cívico-militares ${ }^{2}$ na América Latina destacam, majoritariamente, as ações dos grupos “intelectualizados" da sociedade (estudantes, intelectuais, jornalistas, escritores, artistas) e dos trabalhadores urbano-industriais, organizados em sindicatos e/ou em partidos políticos. Ademais, muitos intelectuais marxistas que estudam esses governos autoritários priorizam como sujeito histórico o proletariado. Dessa forma, como explicar o caso de resistências a regimes militares existentes em países agroexportadores, como o Paraguai? Nesse caso, o conceito de proletariado se manifestaria insuficiente, pois não conseguiria explicar as ações de parcelas expressivas da sociedade, motivo pelo qual utilizaremos o conceito de setores populares.

Luis Alberto Romero, em seu livro Sectores Populares, Cultura y Política: Buenos Aires en la entreguerra (1995), escrito em conjunto com Leandro Gutiérrez, desenvolve o conceito de setores populares ao pensar a constituição dos trabalhadores para além do processo produtivo urbano-industrial e se voltar para os sujeitos e grupos que não necessariamente estão inseridos neste processo produtivo (as mulheres, os idosos, as crianças, os camponeses, os indígenas, dentre outros). É importante frisar que o conceito de setores populares não exclui os trabalhadores urbano-industriais, mas procura pensar suas ações para além do processo produtivo:

[...] en el caso específico de las sociedades latinoamericanas se puso en evidencia el carácter insular de su clase obrera [...] y la amplitud de otros grupos que no se confunden con ella pero que tampoco puedan ser separados completamente, por los cuales pasan algunos de los procesos sociales más significativos. Así hoy, en el caso de las sociedades urbanas, los estudios sobre lo que Gramsci llamo de clases subalternas

\footnotetext{
${ }^{2}$ Benjamín Arditi, em Adios a Stroessner: la reconstrucción de la política en el Paraguay (1992), apresenta a ditadura de Alfredo Stroessner como um poder cívico-militar dominante na política e na sociedade paraguaia, pois o regime contou com o apoio expressivo de parte da sociedade civil e das forças armadas.
}

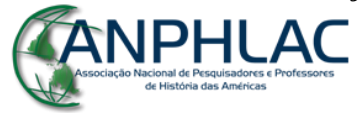

Revista Eletrônica da ANPHLAC, ISSN 1679-1061, №. 18, p. 23-56, jan./jul. 2015.

http://revista.anphlac.org.br/ 
parecen no centrarse exclusivamente en los trabajadores industriales sino en un conjunto más amplio, genéricamente denominado sectores populares urbanos (ROMERO, 2007, p. 27).

Portanto, o conceito apresentado seria mais viável para aplicarmos à sociedade paraguaia, levando-se em consideração as particularidades de sua história. Porém, muitos estudos referentes ao Paraguai silenciam as atuações políticas e sociais dos setores populares, ao destacar seus atores como indivíduos que não faziam parte do processo histórico. Edgar S. de Decca, em 1930 - O silêncio dos vencidos: Memória, história e revolução (1981), mostra como o discurso dos políticos e dos intelectuais silenciou a atuação política dos trabalhadores e projetou sobre eles ações que não faziam parte do cotidiano desse grupo, anulando-os consideravelmente. ${ }^{3} \mathrm{~A}$ academia, "ao recorrer à classe operária ou ao movimento operário como objetos, como abstrações, silenciou os ecos da experiência proletária” (DECCA, 2004, p. 34), ou seja, os discursos acadêmicos emudeceram a voz dos operários.

O autor dá um exemplo deste silenciamento ao afirmar que os intelectuais, após o golpe militar no Brasil em 1964, utilizaram a classe operária como uma abstração em que se fixou um marco histórico para os vencidos, a partir da data do golpe, e silenciaram "a respeito da dimensão práxica dessa classe social" (DECCA, 2004, p. 35). Edgar S. de Decca não pretende "dar voz" aos "vencidos" e os inserir no campo histórico, mas analisar as estruturas discursivas por meio do "silenciamento" dos grupos e dos sujeitos que perderam capital político na conjuntura da Revolução de Trinta no Brasil. Vale ressaltar que De Decca trabalha com o conceito de trabalhadores, mas suas observações são pertinentes também para o caso dos setores populares, como entende Luis Alberto Romero.

Dessa forma, o presente artigo tem como objetivo principal destacar as formas como os setores populares foram representados ${ }^{4}$ na historiografia sobre a ditadura cívico-militar de

\footnotetext{
${ }^{3}$ Cabe salientar que Edgar de Decca analisa, em sua obra, o processo correspondente ao período caracterizado como Revolução de 1930, movimento político brasileiro que depôs o presidente Washington Luiz (1869-1957), mediante um Golpe de Estado articulado por políticos e militares, e proporcionou a ascensão de Getúlio Vargas (1882-1954) à presidência da República.

${ }^{4} \mathrm{O}$ conceito de representações é trabalhado pelo historiador Roger Chartier, que o define como um processo determinado pelos interesses de grupos que os forjam. Daí a necessidade de relacionar os discursos proferidos com a posição de membros que os utilizam. Em outras palavras, as representações seriam imagens da realidade criadas e forjadas por certo grupo social e proferidas por discursos. O termo "representações" significa, assim, as formas de
}

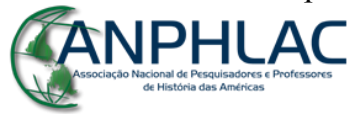

Revista Eletrônica da ANPHLAC, ISSN 1679-1061, №. 18, p. 23-56, jan./jul. 2015.

http://revista.anphlac.org.br/ 
Alfredo Stroessner (1954-1989), sobretudo suas atuações político-sociais. A discussão historiográfica foi selecionada a partir de trabalhos correspondentes a três períodos distintos: a) de 1980 a 1988; b) de 1989 a 1999 e c) de 2000 a 2012. Destacaremos, assim, obras publicadas ainda durante o período do regime de Stroessner, livros lançados durante o processo de democratização do país e, por último, estudos escritos na etapa de reafirmação da democracia no Paraguai.

Essa escolha se baseia na forma como está estruturada a historiografia. No entanto, nosso objetivo é tecer uma crítica às produções historiográficas, que se concentram, quase exclusivamente, a partir do viés político e econômico, não se dando conta de explicar outros processos do período. Tendo em vista que o nosso propósito é detectar a ausência das resistências nesses trabalhos, a perspectiva de aspectos socioculturais é um instrumento para criticarmos essa divisão cronológica, amplamente ressaltada nos estudos clássicos e atuais sobre o stronismo. ${ }^{5}$

\section{A historiografia durante o governo de Stroessner (1980-1988)}

Em maio de 1954, o comandante-em-chefe das Forças Armadas, Alfredo Stroessner (1912-2006), em conjunto com o político colorado Epifanio Méndez Fleitas (1917-1985), promoveu um Golpe de Estado contra o presidente colorado Federico Chaves (1882-1978). Logo após o golpe, Tomás Romero Pereira (1886-1982) assumiu como presidente provisório e, em junho, Stroessner foi nomeado pela ANR para disputar a presidência da república. Em julho, sendo o único candidato, foi eleito presidente por $98,4 \%$ dos votos válidos. No mês seguinte,

como, em distintos espaços temporais, uma determinada realidade social é construída, pensada e dada a ler por meio de delimitações, classificações e divisões que organizam a compreensão do mundo social (CHARTIER, 1990, p. 1617). É importante ressaltar que a definição de "representações" não é a de algo inventado, mas a de uma ferramenta que auxilia na identificação de imagens, por meio dos discursos, de determinada sociedade em um espaço temporal específico.

${ }^{5}$ Em nosso trabalho utilizaremos a expressão Stronismo, frequentemente utilizada pela maioria dos pesquisadores paraguaios que estudam a ditadura de Stroessner. Encontramos, em alguns estudos, expressões como Stronato ou Stroessnerismo, geralmente em pesquisas desenvolvidas por estrangeiros, como dos brasileiros Alfredo da Mota Menezes, em A Herança de Stroessner: Brasil - Paraguai, 1955-1980 (1987), e Julio José Chiavenato, em Stroessner:retrato de uma ditadura (1980).

\section{GANPHLAC}

Revista Eletrônica da ANPHLAC, ISSN 1679-1061, Nº. 18, p. 23-56, jan./jul. 2015.

http://revista.anphlac.org.br/ 
assumiu o mandato presidencial de Chaves (que finalizaria em 1958) e se manteve no poder ininterruptamente até 1989, por meio de eleições fraudulentas.

Sob o lema "Paz y progreso", a ditadura cívico-militar de Stroessner é caracterizada, predominantemente, por seis pontos: 1) violação aos direitos humanos (práticas de torturas físicas e psicológicas, assassinatos, exílios forçados, desaparecimentos, violações sexuais, entre outros) por obra de organismos estatais e paraestatais; 2) clientelismo e paternalismo desenvolvido pelo governo; 3) corrupção massiva entre os órgãos públicos; 4) sistema de repressão e os mecanismos de censura; 5) autoritarismo estatal; 6) "controle" dos veículos da imprensa nacional e da população em geral.

Entre as décadas de 1960 e 1970, o governo de Stroessner sistematizou e estruturou um mecanismo de repressão eficaz, proporcionado por organismos estatais como o Departamento de Investigaciones e a Dirección Nacional de Asuntos Técnicos (La Técnica). Esse sistema repressivo desbaratou inúmeros movimentos armados, desfez distintas tentativas de golpe, perseguiu milhares de pessoas, censurou veículos de comunicação e produções artísticas, forneceu os mecanismos de violação aos direitos humanos e desarticulou ações de oposições político-partidárias.

Nesse período, o Paraguai conheceu uma impressionante modernização econômica, como o estabelecimento das políticas em conjunto com o Brasil, a criação da Usina Hidrelétrica Binacional de Itaipu, a elevação do Produto Interno Bruto (PIB) na década de 1970, a criação de uma classe média expressiva e a construção de obras de infraestrutura no país, como o sistema de água e esgoto. Na década de 1980, o governo viveu uma séria crise político-econômica, pois, com o fim das obras de Itaipu e a continuidade do sistema de corrupção em instituições públicas, o PIB do país caiu consideravelmente, com o aumento da pobreza e a desigualdade social em território nacional.

Durante essa época, mediante o descontentamento pelo governo, a classe média emergente e a sociedade civil intensificaram os protestos públicos, por meio de manifestações e do posicionamento da imprensa nacional. Vale frisar que o processo de oposição políticopartidária e de resistência popular não se iniciou nos anos 1980, ocorreu desde a ascensão de Stroessner, na década de 1950.

\section{GANPHLAC}

Revista Eletrônica da ANPHLAC, ISSN 1679-1061, №. 18, p. 23-56, jan./jul. 2015.

http://revista.anphlac.org.br/ 
Das obras produzidas na última década do governo do general Stroessner, selecionamos: Paraguay bajo Stroessner (1980), de Paul H. Lewis, e Stroessner: retrato de uma ditadura (1980), de Julio José Chiavenato. Produzidas quando o regime ainda era vigente, esses dois livros inspiraram as análises posteriores, tornando-se obras canônicas dos estudos relacionados àquela ditadura.

O historiador estadunidense Paul H. Lewis publicou, no ano de 1980, o livro Paraguay bajo Stroessner, que recebeu uma edição em espanhol em 1986. Lewis busca compreender como foi possível o stronismo se estruturar em uma época caracterizada por instabilidade política, ao analisar a tradição de uma cultura política autoritária que teria existido desde o governo de José Gaspar Rodríguez de Francia (1816-1840) até a ascensão de Stroessner. Além disso, descreve a personalidade do ditador e tenta entender como este consolidou seu poder e lidou com as situações políticas, sobretudo com os membros opositores dentro do Partido Colorado (mais especificamente da ala democrática). As oposições ao regime também são lembradas pelo autor, ao analisar a atuação dos partidos políticos opositores e a posição da Igreja Católica.

No início de seu livro, Lewis afirma que o "Paraguay nunca ha conocido un gobierno democrático [...], la historia de Paraguay es una secuencia ininterrumpida de dictaduras" (LEWIS, 1986, p.15). Além disso, assegura que "la gran mayoría de los gobiernos en Paraguay ascendió al poder ilegalmente, se mantuvo en él a través del fraude y la coerción, y acabó de manera violenta" (LEWIS, 1986, p.15). O autor defende, ainda, que o:

\footnotetext{
Paraguay no cuenta con una tradición de gobierno constitucional ni con procesos democráticos liberales en los cuales inspirarse. Por el contrario, las normas políticas fundamentales de su cultura son autoritarias y todos las comparten. Los grupos fuera de poder pueden proclamar sus ideales democráticos y condenar al gobierno por ser una dictadura, pero los documentos históricos muestran que todos los partidos principales, cuando estuvieron en el poder, trataron de callar a sus opositores. Y cuando han estado fuera del poder ninguno ha dudado en tocar a puerta de los cuarteles (LEWIS, 1986, p. 19).
}

E como os setores populares são representados no livro? Quando apresenta o contexto social e político paraguaio durante a chegada ao poder do general Stroessner, Lewis considera que a política era manejada apenas pelas classes educadas residentes em Assunção e que, fora da capital:

\section{GANPHLAC}

Revista Eletrônica da ANPHLAC, ISSN 1679-1061, Nº. 18, p. 23-56, jan./jul. 2015.

http://revista.anphlac.org.br/ 
La gran mayoría de los paraguayos vivía aislada de la vida moderna e indiferente a ella. No tenían radios ni teléfonos y no recibían ningún periódico - ni hubieran podido leerlos en caso de haberlos recibido. [...] Así, pues, los paraguayos rurales no tenían casi ninguna repercusión en la vida política de su país, salvo las raras ocasiones en que eran movilizados por los líderes de los partidos [grifo meu]. También había algunas familias campesinas que [...] se habían identificado con alguna de las grandes familias terratenientes, de manera que un campesino particular podría llamarse a sí mismo "liberal" o "colorado" [...] y estaría listo para sacrificarse como carne de cañón [grifo meu] en la lucha nacional de los partidos siempre que su patrón se lo pidiera. Pero a menos que sus superiores lo incitaran, el campesino tenía muy pocos vínculos con la política nacional y muy poco interés en ella [grifo meu] (LEWIS, 1986, p. 31).

Lewis se refere ao Paraguai como uma "nación rural, sin grandes ciudades, sin una economía industrial compleja, y sin un sistema altamente organizado de intereses de grupo. $L a$ vasta mayoría de la población es iletrada, pasiva y obediente [grifo meu]" (LEWIS, 1986, p. 218). Quando sintetiza a primeira parte do livro, ressalta que Stroessner não teria ascendido ao poder em um país com tradições cívicas fortes, mas:

[...] donde las masas son pobres e ignorantes [grifo meu], donde los valores sociales ven la política como una lucha por obtener los escasos recursos, como una lucha de todo o nada, y donde el ejército es, por costumbre, la fuerza gobernante por ser la única en imponer el orden, un gobierno como el de Stroessner no está fuera de lugar (LEWIS, 1986, p. 417).

Lewis aponta ainda que o regime se consolidou e se legitimou por três décadas por causa da cultura autoritária do Paraguai e da personalidade do ditador, marcada, em sua opinião, pela autodisciplina e pelo trabalho, já que Stroessner é representado como um verdadeiro estrategista. Além disso, afirma que o ditador se manteve no poder por tantos anos, pois conseguiu modificar o Partido Colorado, transformando-o em um órgão centralizado e disciplinado, capaz de mobilizar o apoio de parcelas expressivas da sociedade - como os camponeses, os trabalhadores urbanos e os militares -, pelo que se formou uma unidade indivisível e autossustentável entre o partido, as Forças Armadas e o governo. As oposições ao regime teriam ficado restritas a grupos politicamente organizados em partidos políticos, como o Partido Revolucionario Febrerista (PRF) e o Partido Liberal (PL), ou ainda à Igreja Católica, considerada pelo autor a adversária mais poderosa do governo.

Paul Lewis, em todo seu trabalho, mostra uma visão desconhecida da realidade paraguaia, com que cria a imagem de uma população pobre e ignorante que legitimou e CANPHLAC

Revista Eletrônica da ANPHLAC, ISSN 1679-1061, Nº. 18, p. 23-56, jan./jul. 2015.

http://revista.anphlac.org.br/ 
consolidou o governo ditatorial. Além disso, em seu livro, o autor representa os setores populares como sujeitos a-históricos, apolíticos e que foram passiveis e omissos à ascensão de Stroessner. Apesar dessa questão, a obra de Lewis é importante por ser o primeiro trabalho de fôlego a analisar o regime de Stroessner e por desenvolver temas importantes como as oposições políticopartidárias e da Igreja Católica, a análise sobre o sistema político autoritário, os mecanismos do governo para se legitimar e as relações diplomáticas entre Paraguai e Estados Unidos.

Esse último ponto é importante, pois o livro de Lewis foi publicado no início da década de 1980, num período em que as relações entre os Estados Unidos e o Paraguai estavam em crise, pois os governos estadunidenses - com destaque para a gestão de Jimmy Carter (19771981) - cobravam uma posição frente à adoção de política de defesa dos direitos humanos e pressionavam uma abertura política e democrática no país. Diante dessa conjuntura específica, um estudo acerca do sistema político paraguaio que, em certa medida, denunciava os mecanismos de violação aos direitos humanos e de um governo não democrático, que contava com uma oposição partidária fraca, reforçaria as pressões estadunidenses sobre o Paraguai, já que o estudo teve uma circulação internacional expressiva.

Também publicado em 1980, o livro Stroessner: retrato de uma ditadura, do jornalista brasileiro Julio José Chiavenato, faz um grande panorama da ditadura do general Alfredo Stroessner, desde sua subida ao poder até o ano de 1980.

Quando o autor aborda a atuação dos setores populares, caracterizados por ele como "o povo paraguaio", destaca que este grupo, em um primeiro momento, foi a "base que levou o Partido Colorado ao poder" (CHIAVENATO, 1980, p. 89), pois o povo, “vivendo a opressão dos governos liberais, sem nenhum partido político de massas a organizá-lo, aprendeu a identificar-se com sua única opção: o Partido Colorado" (CHIAVENATO, 1980, p. 89).

O que o autor destaca é a participação dos camponeses paraguaios na Revolução de 1947, que trouxe o Partido Colorado de volta ao poder nacional. ${ }^{6} \mathrm{Ou}$ seja, em um primeiro momento os

\footnotetext{
${ }^{6}$ A Revolução de 1947 iniciou-se com uma rebelião liderada por militantes do PRF descontentes com o governo de Higinio Morínigo (1940-1948). Apoiados por distintos grupos, como setores das Forças Armadas e membros do PCP, o movimento anti-Morínigo foi ganhando força, enquanto o Partido Colorado, com a intenção de proteger a ditadura de Morínigo, formava milícias campesinas que barravam a atuação dos revolucionários. Após cinco meses, os rebeldes foram vencidos pelas milícias coloradas e, consequentemente, o Partido Colorado, longe do poder por 42
}

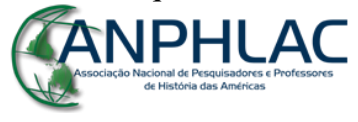

Revista Eletrônica da ANPHLAC, ISSN 1679-1061, №. 18, p. 23-56, jan./jul. 2015.

http://revista.anphlac.org.br/ 
setores populares apoiaram a ascensão dos colorados ao poder, mas com o tempo perceberam que "o coloradismo de Stroessner não diferia muito do velho liberalismo" (CHIAVENATO, 1980, p. 90) e, também, se deram conta de que "Stroessner era mais impiedoso que todos os antigos governos que já oprimiram o povo paraguaio" (CHIAVENATO, 1980, p. 90). A seguir, realça que toda a:

[...] oposição é sufocada, assassinada ou exilada [grifo meu] - a ditadura de Stroessner é eficiente na repressão. Fica no Paraguai, então, um povo sem vanguarda política a organizá-lo [grifo meu], perdido dentro da miséria social e da falta de perspectivas, mas que vai se "politizando" pela própria opressão social que sofre [grifo meu] (CHIAVENATO, 1980, p. 91).

Para Chiavenato (1980, p. 09), o povo paraguaio trabalha demasiadamente, "vive muito mal e sobrevive com terror". O medo, "entranhado, plasmado com sangue e muita violência", seria o responsável por fazer com que o povo perdesse "a vontade de reagir ante a espoliação, a brutalidade de um sistema que se baseia no saque da Nação". Ou seja, o medo, o terror e a repressão são introduzidos pelo autoritarismo estatal nas estruturas sociais, e isso faria com que os setores populares, uma vez "reprimidos" e descontentes com a política e com as instâncias judiciais do país, ficassem sem uma vanguarda política que os pudesse organizar. Apesar disso, a partir da opressora realidade social em que estavam inseridos, se "politizavam" a cada dia. Com uma visão marxista, o autor dá alguns caminhos de instituições que poderiam organizar e conscientizar os setores populares, como as guerrilhas armadas e a Igreja Católica.

Quando apresenta a participação das guerrilhas durante os primeiros anos do regime stronista, Chiavenato destaca o papel oposicionista da Frente Unido de Liberación Nacional (FULNA), uma organização ligada ao Partido Comunista Paraguayo (PCP) que lutou entre os anos de 1960 e 1961 e foi violentamente reprimida pelos militares. Em determinado período, a guerrilha, com poucos combatentes e sendo atacada constantemente pelas forças militares, formou grupos de camponeses com o objetivo de tentar "educar politicamente o homem do campo" (CHIAVENATO, 1980, p. 128).

anos, assumiu as bases do Estado. Em 1948, Morínigo é deposto por militares colorados e assume Juan Manuel Frutos.

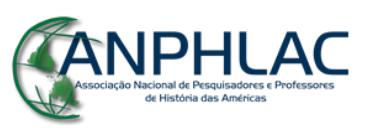

Revista Eletrônica da ANPHLAC, ISSN 1679-1061, №. 18, p. 23-56, jan./jul. 2015.

http://revista.anphlac.org.br/ 
Quanto à Igreja, o autor afirma que ela foi:

[...] a última instituição que permaneceu ao lado do povo. Teve a capacidade de começar a organizá-lo de 1969 até 1972 [grifo meu]. Continuou ao seu lado através de movimentos leigos [...] mas não foi capaz de resistir quando os próprios movimentos populares foram vencidos [grifo meu], a partir da grande repressão que liquidou as Ligas Agrárias e prendeu, torturou e matou os líderes camponeses (CHIAVENATO, 1980, p.118).

Finalizando sua obra, o autor, numa visão "messiânica", afirma que os setores populares observavam atentamente as crises do governo e que o:

Paraguai inteiro espera a queda de Stroessner, para ver o que vai acontecer. Depois, as oposições traçarão uma estratégia de luta [grifo meu]. Pela primeira vez é tão evidente que a ditadura está no fim, que os mais importantes líderes da oposição não querem incidir em antigos erros. Um deles: mobilizar o povo antecipadamente, provocando a violência repressiva, perdendo a vanguarda que pode lutar contra a ditadura de Stroessner [grifo meu]. Há no Paraguai um clima de espera. Quando Stroessner cair [...] surgirá uma voz popular, cansada, torturada, violentada, faminta mas plena de esperança [grifo meu]: Ahora compañero... (CHIAVENATO, 1980, p.147-148).

Enquanto Lewis silencia a atuação político-social dos setores populares, mostrando-os como ignorantes, passivos, apolíticos e manipuláveis, à mercê das decisões partidárias conforme a conjuntura de uma época especifica, Chiavenato apresenta os setores populares como sujeitos que aos poucos vão se "politizando", diante das opressões e da realidade social na qual estavam inseridos. Entretanto, o jornalista brasileiro possui um grande problema em sua obra: o apego ao modelo de vanguarda. Essa questão pode ser explicada por sua posição político-ideológica, já que se identifica com a vertente marxista e isso se reflete em suas análises. Além disso, mescla esse vanguardismo com partidos políticos, o que era comum nesse momento específico. O problema é que essa análise permanece atualmente nos estudos sobre o período.

Também existe o problema de temporalidade: se em Lewis parece haver uma eterna repetição da história paraguaia, sobretudo quanto aos modelos políticos e autoritários, em Chiavenato há uma perspectiva de rompimento, mas para um futuro incerto. Isso pode estar associado à visão sobre o Paraguai de ambos os autores. Enquanto Lewis acredita em uma sociedade atrasada, cuja história seria um "eterno retorno", Chiavenato considera as particularidades do país e observa um futuro sem perspectivas, porém, no momento em que o

\section{GANPHLAC}

Revista Eletrônica da ANPHLAC, ISSN 1679-1061, Nº. 18, p. 23-56, jan./jul. 2015.

http://revista.anphlac.org.br/ 
regime caísse, os paraguaios iriam se libertar da opressão ditatorial, esperançosos com o fim do governo stronista.

Essas obras trazem um panorama do que foi o regime de Alfredo Stroessner, desde sua consolidação, em 1954, até o ano de 1980, quando o governo estava entrando em crise. Apesar de suas contribuições, esses estudos apresentam dificuldades em apreender as formas de atuação da sociedade paraguaia, pois consideram que a ditadura conseguiu silenciar os setores populares, tornando-os passivos em face do autoritarismo, da repressão estatal, do clientelismo e da corrupção. Porém, esses livros foram publicados quando o regime ainda existia, em dois países distintos (Brasil e Estados Unidos), por autores que não tinham condições de conhecer as particularidades do Paraguai, haja vista que o país vivia sob um governo autoritário e o desenvolvimento de pesquisas era controlado.

\section{As produções durante o período de democratização (1989-1999)}

As crises internas do Partido Colorado também se acentuam nesse período, já que o partido foi dividido em duas alas principais: os "tradicionalistas", que se opuseram ao sistema stronista, e os "militantes", que apoiaram o sistema político vigente. Diante dessa conjuntura, a estrutura política do regime perdeu força e deu margem para possíveis insurreições, orquestradas pelas Forças Armadas e/ou pelo Partido Colorado, o que de fato ocorreu em fevereiro de 1989. Liderado pelo general Andrés Rodríguez (1923-1997), consogro do ditador, um Golpe de Estado depôs Stroessner, que se exilou no Brasil. Rodríguez assumiu como presidente provisório e, no mesmo ano, foi constitucionalmente eleito Chefe do Governo paraguaio, com 75,9\% dos votos válidos, governando até 1993.

Com a queda do regime de Stroessner e a eleição de Rodríguez, o Paraguai iniciou um processo de democratização. Nesse período houve uma efervescência de produções sobre a ditadura passada e maior movimentação político-social, particularmente em relação aos crimes cometidos pelo stronismo. Deste período selecionamos: Stroessner: la extinción de un modelo político (1989), de Fernando Masi; Adiós a Stroessner: la reconstrucción de la política en el

\section{GANPHLAC}

Revista Eletrônica da ANPHLAC, ISSN 1679-1061, Nº. 18, p. 23-56, jan./jul. 2015.

http://revista.anphlac.org.br/ 
Paraguay (1992), de Benjamín Arditi; e Es mi informe: los archivos secretos de la policía de Stroessner (1994), de Alfredo Boccia Paz, Myrian González e Rosa Palau.

Ainda em 1989, o sociólogo paraguaio Fernando Masi publicou o livro Stroessner: la extinción de un modelo político, que tinha como objetivo analisar o autoritarismo político do stronismo, destacando crítica e historicamente a relação entre o ditador e o Partido Colorado, assim como a crise do sistema colorado-stronista. Além disso, tentou compreender a situação político-social após a queda de Stroessner, um assunto em pleno destaque na época.

Ao definir o autoritarismo tradicional paraguaio, Masi considera que uma das peculiaridades desse sistema era a existência do Partido Colorado como "encargado de repartir la prebenda y desmovilizar a la sociedad civil" (MASI, 1989, p. 13-14) e que a "sociedad civil, fragmentada, se muestra, sin embargo, incapaz de elaborar proyectos alternativos de dominación política y de movilización [...]" (MASI, 1989, p. 42). Assim como outros estudos, Masi corrobora com a ideia de que o Partido Colorado reprimiu e desmobilizou a sociedade, dificultando o surgimento de projetos políticos alternativos, inclusive após a queda da ditadura.

Porém, quando aborda a crise da ditadura, o autor destaca a importância que tiveram as manifestações sociais da década de 1980, enfatizando que no campo as:

Ligas Agrarias Cristianas habían constituido el primer intento serio de defensa de los intereses del campesinado [grifo meu], hasta su desaparición a fines de los años 70 . El gradual empobrecimiento de las capas rurales [...] llevó - a principios de los ochenta - a una lucha por la tierra, sin precedentes, constituyéndose decenas de organizaciones campesinas [grifo meu]: desde aquellas que reclamaban tierras despojadas, pasando por aquellas que se agremiaban para la producción, hasta aquellas que reclamaban mayor justicia social en el país. Las invasiones de tierras y los enfrentamientos con las fuerzas policiales y militares se hicieron constantes, y el gobierno tuvo que ceder en varias ocasiones procediendo a la expropiación en favor de los campesinos [grifo meu]. A estos sectores se sumaban otros como nuevas organizaciones de Derechos Humanos, comisiones vecinales, de mujeres [...]. [...]. Esta reactivación de la sociedad civil paraguaya llegaba a su momento más dinámico durante las movilizaciones de la primera mitad del año 1986, las cuales también volvían a reactivar a los aparatos represivos del régimen. [...] La Iglesia Católica [...] volvía a convertirse en un actor social y político fundamental en plena etapa de crisis del régimen autoritario tradicional. $Y$ en los dos últimos años se convertía en uno de los canales aprovechados por sectores sociales y políticos para movilizarse y realizar su protesta social [grifo meu] (MASI, 1989, p. 64$65)$.

\section{GANPHLAC}

Revista Eletrônica da ANPHLAC, ISSN 1679-1061, Nº. 18, p. 23-56, jan./jul. 2015.

http://revista.anphlac.org.br/ 
Podemos observar que Masi considera as atuações político-sociais dos setores populares e destaca suas mobilizações durante as décadas de 1970 e 1980, em favor de distintos objetivos, como, por exemplo, maior justiça social e uma abertura política no país. Além disso, a Igreja Católica teria desempenhado um papel político e social importante como um instrumento aproveitado pelo povo para se mobilizar e realizar manifestações. Diferentemente da visão de Chiavenato, para Masi a Igreja não assumiu uma posição de vanguarda, porém foi um porta-voz que canonizou as reivindicações sociais. Entretanto, o autor acaba corroborando as ideias tradicionais de que os setores populares foram desarticulados por estruturas partidárias e estatais.

Mesmo assim, o estudo de Masi nos ajuda a entender o processo da crise política ao final do regime e das perspectivas para se pensar uma organização social e política sem as estruturas e mecanismos desenvolvidos pelo stronismo e por uma parcela do Partido Colorado. Nesse material se refletem as incertezas e as possíveis perspectivas em relação às manifestações políticas de uma sociedade que vivia os últimos dias de um sistema autoritário que a governou por 34 anos.

Lançado em 1992, o ensaio Adiós a Stroessner: la reconstrucción de la política en el Paraguay, do politólogo paraguaio Benjamín Arditi, busca entender o início do processo democrático no país, quando enfatiza as mudanças governamentais ocorridas e analisa as estruturas sociais e políticas do regime autoritário de Stroessner. No prólogo do livro, o autor afirma que o stronismo foi um método de poder personalista, hermético e relativamente imutável, que tinha como sistema legitimador a tríade do poder e desenvolvia a doutrina da "unidad granítica del coloradismo", que não aceitava dissidências internas. A institucionalização da corrupção, em conjunto com a lógica clientelista "del intercambio de favores por obediencia, sirvieron para generar un consenso pasivo cómplice para su gestión” (ARDITI, 1992, p.10). Dessa forma, a aplicação de uma "estrategia de corporativismo estatal selectivo permitió la desmovilización de la sociedad civil y la recomposición de sus organizaciones bajo la tutela gubernamental" (ARDITI, 1992, p.10-11).

A seguir, afirma que a:

\section{GANPHLAC}

Revista Eletrônica da ANPHLAC, ISSN 1679-1061, №. 18, p. 23-56, jan./jul. 2015.

http://revista.anphlac.org.br/ 
[...] habilidad política y el empleo del terror selectivo permanente permitió que el régimen mantuviera a la oposición débil y dividida durante décadas. De esta manera se proyectó una imagen de omnipotencia del caudillo y del régimen y, a la vez, se fomentó un sentimiento generalizado de impotencia y vulnerabilidad en la población. El miedo y la creencia en la futilidad de toda iniciativa son excelentes disuasivos para la acción opositora en cualquier latitud (ARDITI, 1992, p.11).

Partindo desses trechos apresentados, Arditi acredita que a sociedade paraguaia foi desmobilizada e que o sistema repressivo, que causou medo e terror, foi responsável por um sentimento de submissão e obediência entre as camadas populares do país. O Estado paraguaio seria o poder supremo da decisão, "controlando sin poder ser controlado efectivamente por los ciudadanos, ordenando sin que se pueda dar órdenes, imponiendo sin que se pueda imponer algo a su vez" (ARDITI, 1992, p. 18-19). Esse Estado soberano, por sua vez, empregava o princípio de legalidade como uma forma de "desarmar a la sociedad, imponiendo un orden rigurosamente controlado" (ARDITI, 1992, p. 21). Adiante, ressalta que o regime:

[...] no sólo apeló a la legalidad y la fuerza para fortalecer al núcleo estatal y domesticar a la sociedad, sino también aplicó una estrategia de control, desmovilización y disciplinamiento permanentes. Los actores que en otros sistemas serían portadores de opciones alternativas - partidos políticos y movimientos sociales de carácter campesino, sindical, estudiantil, urbano, profesional u otro - sufrieron un continuo desgaste a través del acoso permanente a sus organizaciones (ARDITI, 1992, p. 28).

Dessa forma, Arditi afirma que o stronismo controlou e desmobilizou distintas organizações e sistemas sociais, com que pacificou a população e gerou um sentimento impotente entre as categorias populares. $\mathrm{O}$ regime elaborou estratégias que afetaram a vida cotidiana da sociedade, ao desenvolver um “proceso simultáneo de 'desarme' de ésta mediante el desestímulo de iniciativas de control ciudadano (ARDITI, 1992, p. 34)", ou seja, um sistema de desmobilização, desarticulação e disciplinamento dos setores populares. Assim, o regime utilizou um esquema de poder rígido, fechado e autoritário, que:

[...] permitía minar y desarticular, a menudo en forma violenta, contraestrategias que surgían desde la sociedad o desde el espacio político-partidario de la débil sociedad política paraguaya [grifo meu]. [...]. La productividad del stronismo, como modelo ordenador predominantemente excluyente consistió en general "buenos sujetos", sólo que eran sujetos pasivos [grifo meu], vinculados con el Estado a través de una estructura verticalistas. Los "buenos sujetos" buscados por el poder ordenador eran aquellos que pudieran ser controlados o sometidos sin que, a su vez, intentaran controlar o someter al controlador [grifo meu] (ARDITI, 1992, p. 52-53).

\section{GANPHLAC}

Revista Eletrônica da ANPHLAC, ISSN 1679-1061, Nº. 18, p. 23-56, jan./jul. 2015.

http://revista.anphlac.org.br/ 
Nessa perspectiva, o autor considera que o Paraguai, durante o governo de Stroessner, foi um "Estado onívoro", que possuiria como característica principal a existência de um poder "cuyo impulso motor pone de manifiesto el anhelo o la ambición de "devorar" [...] toda diferencia o forma social que no se vincule con el núcleo decisionista de un modo vertical, jerárquico y subordinado [...]” (ARDITI, 1992, p. 57). Além de todo esse processo, ocorreu a:

[...] formación de una cultura política del sometimiento que descansaba sobre la represión, el miedo, el rígido verticalismo y, más importante, sobre el relativo estancamiento de fuerzas capaces de ofrecer una resistencia al poderoso de turno y alternativas viables a la sociedad en conjunto. Esta cultura del sometimiento [...] trasciende los espacios propiamente "políticos". Penetra en el quehacer cotidiano del pueblo tanto en los espacios "estatales" como "societales", sea entre oficialistas u opositores, dirigentes o dirigidos, patrones o empleados (ARDITI, 1992, p. 199-205).

Esse fragmento apresenta a noção de uma cultura política de submissão que utilizaria o temor para controlar atitudes de resistências à ordem vigente e autoritária, e que esse sistema sairia das estruturas político-partidárias para se inserir no âmbito cotidiano e social. Além disso, o texto de Arditi traz duas questões importantes: a "fachada democrática", como elemento de desmobilização; e o controle não somente dos setores populares, mas também dos movimentos oposicionistas, inclusive dos próprios colorados. Diante disso, como explicar, por exemplo, a crise da "tríade do poder"? Essa indagação não é respondida na obra, fica à mercê de estudos posteriores.

O livro de Arditi é importante, pois traz elementos fundamentais para pensarmos a estrutura da sociedade paraguaia, que começava a desestabilizar lentamente as estruturas

políticas stronistas. Apesar de desenvolver reflexões interessantes, como a questão do cotidiano e da cultura política, as visões do autor ainda perpassam um viés político-econômico, não se considerando os aspectos culturais.

No dia 22 de dezembro de 1992, foram encontrados em uma delegacia de polícia em Lambaré, a 30 quilômetros da capital paraguaia, centenas de informes e arquivos policiais da última ditadura vivida no país, além de documentos referentes a outros regimes autoritários do Cone Sul. Esse movimento foi orquestrado, principalmente, pelo juiz José Agustín Fernández e o

\section{GANPHLAC}

Revista Eletrônica da ANPHLAC, ISSN 1679-1061, Nº. 18, p. 23-56, jan./jul. 2015.

http://revista.anphlac.org.br/ 
advogado Martín Almada. O conjunto de documentos encontrados é conhecido como "Archivo del Terror" e foi levado para o Palácio de Justiça, onde permanece até hoje.

Um ano e meio depois, em 1994, o jornalista e médico paraguaio Alfredo Boccia Paz e as pesquisadoras paraguaias Myrian González e Rosa Palau escreveram, em conjunto, o livro Es mi informe - Los archivos secretos de la policía de Stroessner, que tem como objetivo mostrar alguns documentos existentes no arquivo com toda a sistematização do aparelho repressivo do Estado. Essa estrutura era composta pelo Departamento de Investigaciones e a Dirección de Asuntos Técnicos. Em ambos os órgãos, diversas pessoas foram torturadas (tanto psicológica como fisicamente), violentadas sexualmente e assassinadas por funcionários estatais. Logo no início, os autores relatam que, no começo do processo de seleção dos arquivos, em 1993, se depararam com as seguintes questões:

¿cómo encontrar aquellos documentos que pudieran servir como evidencia de los abusos cometidos o como testimonio y ejemplo del control enfermizo al que fue sometida la sociedad durante esa época de ignominia? (BOCCIA PAZ, GONZÁLEZ, PALAU, 2006, p. 37).

Os autores, ao tratar sobre o sistema repressivo orquestrado pelo stronismo, lembram que há muito tempo o Paraguai havia se convertido em uma "República do Medo". Isso se justificaria por uma "opresión tan prolongada había roto muchos de los vínculos de resistencia y solidaridad de la sociedad. La exagerada vigilancia del regímen producía temor paralizante que silenciaba la crítica” (BOCCIA PAZ, GONZÁLEZ, PALAU, 2006, p.183). Apesar de afirmar que a sociedade paraguaia vivia refém do medo dos tentáculos mortíferos produzidos por órgãos estatais, o livro traz muitas evidências de que, mesmo com o terror que reinava nas estruturas sociais do país, os setores populares resistiram, contradizendo a ideia de uma força superior que paralisava politicamente esses grupos sociais.

No informe confidencial de número 209, escrito em 1963 e encaminhado para a delegacia de polícia, constam alguns escritos de diversas paredes e muralhas de Assunção, que depois foram apagados pelos profissionais do departamento de "tallares", durante os dias da Semana Santa. As mensagens escritas eram:

\section{GANPHLAC}

Revista Eletrônica da ANPHLAC, ISSN 1679-1061, Nº. 18, p. 23-56, jan./jul. 2015.

http://revista.anphlac.org.br/ 
1. Denunciamos el asesinato del campesino IRENE GODOY en la Guardia de Seguridad [grifo meu]. "FEDRE". San José y José Berges.

2. Fraude electoral. "MOPOCO". Rosa Peña y José Berges.

3. Cese tortura del estudiante GALEANO. Mcal. López y Constitución. [...]

9. ALON, ALON, ALON. Yegros y Herrera. [...]

11. Abajo Stroessner [grifo meu]. "ALON". Alberdi e/ Estrella y Olliva.

12. Muera Duarte Vera. "D.F.U.P." Juan E. O'Leary e/ Oliva y Estrella [...]

15. La comunidad no vive tranquilo [grifo meu]. Brasil y Tte. Fariña.

21. Libertad al patriota Mangabeira. "PUTO. VIVA LA REVIOLUCION". Fdo. de la Mora casi Gaspar R. de Francia. [...] (BOCCIA PAZ, GONZÁLEZ, PALAU, 2006, p. 95).

Observamos no trecho acima que, por mais que os organismos de vigilância introduzissem na população um medo constante, os setores populares atuavam politicamente, ocupando espaços públicos e se manifestando conforme as condições da realidade em que estavam inseridos. Apesar das limitações que existiam, essa atitude contradiz muitos autores, que afirmam que o povo paraguaio foi desmobilizado politicamente e que não possuía uma cultura de ocupar o espaço público como uma forma de se manifestar politicamente.

Não podemos afirmar, com segurança, que as pichações foram feitas por membros dos "setores populares", porém essa ação indica que certos sujeitos e grupos tinham outras referências sobre o que ocorria naquele período, e estas contribuíram, por exemplo, para as manifestações das décadas de 1980, que estavam relacionadas com a crise econômica e também eram de natureza estritamente político-social.

Outro caso sistemático foi o ocorrido na região de Caaguazú, em março de 1980. Um grupo de camponeses da colônia Acaray (ou Nova Esperança), a poucos metros da Ciudad Puerto Stroessner (atualmente Ciudad del Este), tomou uma atitude desesperadora. Diante da opressão exercida pelo Exército para que abandonassem suas terras e cultivos, decidiram “assaltar” um ônibus com a intenção de chegar a Assunção para solicitar às autoridades do Instituto de Bienestar Rural (IBR) os títulos de propriedade de seus territórios e denunciar à opinião pública a angustiosa situação (BOCCIA PAZ, GONZÁLEZ, PALAU, 2006, p. 270). Como mostra um trecho do informe encaminhado ao chefe de polícia:

1. Hoy [...] a la altura del $\mathrm{Km} \mathrm{27,} \mathrm{de} \mathrm{la} \mathrm{ruta} \mathrm{Ciudad} \mathrm{Pte.} \mathrm{Stroessner-Asunción,}$ ascendieron al micro ómnibus [...] aproximadamente 20 a 25 personas, algunos uniformados de verde mate, otros de civil [grifo meu] e todos a cargo de un supuesto

\section{CANPHLAC}

Revista Eletrônica da ANPHLAC, ISSN 1679-1061, Nº. 18, p. 23-56, jan./jul. 2015.

http://revista.anphlac.org.br/ 
militar, [...] quienes se encontraban armados con revólvers, rifles y puñales. Los que se encontraban de civil usaban barbas [grifo meu].

2. Los sujetos en cuestión se identificaron como "guerrilleros campesinos" [grifo meu], manifestando estar en contra del gobierno nacional (BOCCIA PAZ, GONZÁLEZ, PALAU, 2006, p. 270).

Como bem demonstram os autores, os camponeses catalogados como guerrilheiros pela polícia não tinham armas, víveres ou equipes, além de serem apenas adolescentes. A resposta do regime foi brutal, pois enviou uma força tática expressiva, cercou os camponeses e os massacrou. A grande maioria dos participantes do assalto ao ônibus morreu. Já o líder Victoriano Centurión conseguiu fugir, refugiando-se na Embaixada do Panamá. Como resposta, a Polícia de Investigaciones enviou um grupo de militares para o departamento de Caaguazú e do Alto Paraná, que saqueou e assaltou a colônia Acaray. Muitos camponeses foram torturados e assassinados pelas forças repressivas do regime (BOCCIA PAZ, GONZÁLEZ, PALAU, 2006, p. 271-273).

O caso de Caaguazú mostra as formas de resistência dos setores populares ao governo de Stroessner. O medo e o terror inseridos na sociedade, segundo os autores, não impediu a ação desses camponeses que, munidos de uma consciência crítica e política acerca de sua realidade social, tomaram uma atitude para reivindicar seus direitos e denunciar as opressões vividas. Como bem destacam os escritores do livro, a desculpa do regime para a violência e a repressão foi associar esses grupos com guerrilheiros, de modo a justificar as torturas e os massacres na região. É interessante notar que esse caso também foi utilizado politicamente pelo PCP que, no jornal "Adelante" de 1980, associou o sequestro do ônibus a uma ação de um grupo guerrilheiro camponês (BOCCIA PAZ, GONZÁLEZ, PALAU, 2006, p. 274-275). Tanto o regime quanto os partidos opositores utilizaram as atitudes conscientes de um grupo camponês para justificar a repressão violenta assim como a crítica ao stronismo.

Além de trazer à tona casos paradigmáticos e até então secretos, o livro ajuda a contradizer algumas posições oficiais do regime, por meio de documentos e informes de presos. Além disso, contribui para observar como o modelo de repressão do governo ultrapassou as delegacias e os muros dos quartéis militares e adentrou nos lares, nas reuniões familiares e de amigos, nas festas. Isso só foi possível por causa da participação dos pyragues, que relatavam

\section{GANPHLAC}

Revista Eletrônica da ANPHLAC, ISSN 1679-1061, Nº. 18, p. 23-56, jan./jul. 2015.

http://revista.anphlac.org.br/ 
tudo para os órgãos estatais e terminavam sempre seu testemunho com a seguinte frase: "Es $m i$ informe”.

O livro reproduz a imagem de que a população paraguaia era controlada pelo medo da repressão articulada pelos organismos estatais, o que provocou um engessamento das atitudes políticas de grupos sociais. Entretanto, apresenta casos específicos ou coletivos que demonstram que o temor não impediu que setores populares atuassem politicamente e reivindicassem seus direitos fundamentais, conforme o contexto em que estavam inseridos, fosse na luta armada, fosse em queixas enviadas ao IBR, ou até mesmo em protestos ou pichações em muros assuncenos.

Terminamos a análise desse livro citando justamente o prólogo da $1^{\mathrm{a}}$ edição, escrito por Augusto Roa Bastos, onde afirma que a:

[...] escala jerárquica de responsables principales, informantes, esbirros, torturadores, desplegada en todo el país como una red tentacular inescapable, convirtió al dictador en el jefe único y supremo e la guerra interna policíaca que libró contra la colectividad, es estado de sitio permanente. La responsabilidad suprema del jefe no eximia de culpa por omisión o negligencia a los subordinados desde el más alto al más bajo rango (BOCCIA PAZ, GONZÁLEZ, PALAU, 2006, p. 50).

Apesar de denunciar todas as formas de colaboracionismo com a ditadura, até mesmo das pessoas que ocupavam posições inferiores na estrutura governamental, o autor não estende essa omissão ou negligência para toda a sociedade paraguaia, já que a "crónica del terror no era desconocida. Pero sólo podía circular como el rumor del miedo, la única forma silenciosa de conciencia pública que existía por entonces” (BOCCIA PAZ, GONZÁLEZ, PALAU, 2006, p. 28-29).

Diferentemente de Arditi e de Chiavenato, que confundem o medo com apoio ao governo, Roa Bastos considera que o terror, que não era desconhecido entre os setores populares, era a única consciência pública que existia nesse período. Assim, para o literato, o medo não seria uma maneira de manipular a sociedade, tampouco desarticulá-la politicamente.

Os trabalhos apresentados nessa secção foram desenvolvidos após a queda de Stroessner e durante o processo de construção de uma democracia política. Nesse período, os intelectuais, os movimentos sociais e as organizações político-partidárias se voltaram ao passado para

\section{GANPHLAC}

Revista Eletrônica da ANPHLAC, ISSN 1679-1061, №. 18, p. 23-56, jan./jul. 2015.

http://revista.anphlac.org.br/ 
construir uma história do stronismo destacando os anos de censura e repressão e também esclarecendo para a população paraguaia os anos em que esta viveu sob a tutela do general Stroessner.

Na ebulição das memórias não oficiais oriundas principalmente das vítimas do Estado, e na formação de movimentos sociais, essas produções contribuíram para a construção de uma memória coletiva e de uma história reescrita sobre a ditadura de Alfredo Stroessner. É importante ressaltar que o processo democrático vivia seu primeiro grande embate: em 1999, com o assassinato do vice-presidente Luis Argaña, o presidente colorado Raúl Cubas Grau (1998-1999) renunciou ao cargo, devido às manifestações sociais e populares que pediam o fim de seu mandato, pois seria acusado de envolvimento com o assassinato de seu vice. Uma dessas manifestações que proporcionou a renúncia de Cubas Grau resultou no massacre do "Março Paraguaio", em que sete jovens que protestavam em Assunção foram mortos por forças policiais. A democracia política nesse momento vivia uma crise e precisava ser reafirmada como tal. Diante desse contexto, seguimos com as produções publicadas entre os anos de 2000 e 2012.

\section{A historiografia durante a fase de reafirmação da democracia (2000-2012)}

Entre os anos de 2000 e 2012, fase de reafirmação do processo democrático do Paraguai, foram lançados muitos trabalhos sobre o período stronista; destacamos cinco deles: Autoritarismo e democracia no Paraguai contemporâneo (2000), de Fábio Anibal Jara Goiris; El Último Supremo: La Crónica de Alfredo Stroessner (2003), de Bernardo Neri Farina; El régimen de Stroessner y la resistencia indígena (2007), de Rene D. Harder Horst; Paraguay: Ciclos adversos y Cultura Política (2008), de Fábio A. Jara Goiris; e Paraguay, la Larga Invención del Golpe: el stronismo y el orden político paraguayo (2012), de Lorena Soler.

Escritos após uma década do fim do regime de Stroessner, esses trabalhos trazem à luz uma nova escrita da história do período stronista e também, intrinsecamente, o processo político que a sociedade vivia nesse período, como a reafirmação do sistema democrático, a maior participação civil no governo, as participações dos partidos opositores à ditadura (PRF e Partido Liberal Radical Auténtico) na política nacional, os movimentos sociais paraguaios que cobraram

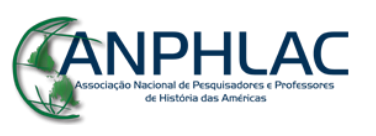

Revista Eletrônica da ANPHLAC, ISSN 1679-1061, N. 18, p. 23-56, jan./jul. 2015.

http://revista.anphlac.org.br/ 
uma resposta do Estado frente às violações aos direitos humanos sofridas na última ditadura, a crise do coloradismo e a ascensão do presidente Fernando Lugo (2008-2012), que pôs fim a 60 anos de hegemonia colorada. ${ }^{7}$

Publicada em 2000 pelo politólogo paraguaio Fábio Anibal Jara Goiris, a obra Autoritarismo e democracia no Paraguai contemporâneo tem como objetivo analisar o processo de transição política no Paraguai, iniciado após o golpe de 1989, que depôs o governo do general Stroessner. Tendo como marco temporal o contexto político e socioeconômico do fim do stronismo, em 1989, até as eleições gerais de 1993, o autor mostra em seu estudo a trajetória política do Partido Liberal Radical Auténtico (PLRA), focalizando seu papel político-partidário como principal partido opositor.

A intenção de Jara Goiris é destacar como as velhas estruturas políticas, criadas durante o stronismo, ainda persistem no Paraguai mesmo após o período de democratização do país. Assim, o Paraguai não teria uma tradição liberal-democrática, o que justifica as permanências do stronismo no país. Entretanto, como as atuações dos setores populares aparecem na obra de Jara Goiris?

Na primeira parte do livro, ao fazer uma discussão teórica sobre o conceito de autoritarismo, apresenta interpretações de autores que acreditam que o governo de Stroessner controlou e desmobilizou a sociedade, já que as "organizações sociais transformaram-se em mecanismos de controle social e deixaram de ser autênticas instâncias de participação popular para canalizar demandas setoriais" (GOIRIS, 2000, p. 54). ${ }^{8}$ Apesar disso, afirma que do:

[...] lado do regime, a violência e a massificação da repressão mostraram a incapacidade do poder central de adaptar-se às novas circunstâncias sociais. Ao mesmo tempo verifica-se o enfraquecimento das organizações de oposição ao regime, independente das suas opções ideológicas. Paradoxalmente, o debilitamento das organizações políticas apressou [...] o desencadeamento de um processo unitário antiditatorial que estava em gestação na sociedade civil, evidenciando a possibilidade de uma consciência social mais desenvolvida (GOIRIS, 2000, p. 63).

\footnotetext{
${ }^{7}$ Dos cinco trabalhos citados, apenas três foram publicados após a ascensão de Lugo à presidência paraguaia.

${ }^{8}$ É importante ressaltar que essa perspectiva citada por Goiris é da obra de José Luis Simón, intitulada La dictadura de Stroessner y los Derechos Humanos (1990).
}

\section{GANPHLAC}

Revista Eletrônica da ANPHLAC, ISSN 1679-1061, Nº. 18, p. 23-56, jan./jul. 2015.

http://revista.anphlac.org.br/ 
Ou seja, o enfraquecimento das organizações político-partidárias teria contribuído para que estas deixassem suas divergências de lado, pelo menos temporariamente, e se unissem contra o adversário em comum: a ditadura Stroessner. Além disso, em outro capítulo, Jara Goiris, ao destacar a questão da reforma agrária e do término da construção da Usina Hidrelétrica de Itaipu, afirma que os "campesinos sem terra multiplicavam-se e, somados aos desempregados da hidroelétrica, começaram a exercer pressões populares sobre o mercado de que era de pouco expansão" (GOIRIS, 2000, p. 86). Como vimos, os camponeses pressionaram o regime e suas políticas públicas.

Os setores populares, no estudo de Jara Goiris, não são representados como um forte ator social e político, mas como dependentes do Partido Colorado, visto como uma instituição que mobilizava as "massas", e que foram organizados, em um período específico, pela Igreja Católica, como no caso das Ligas Agrarias Cristianas (LAC). Com o fim do regime, os setores populares, a partir de uma opressão social e econômica, começaram a pressionar o governo.

O grande protagonista do estudo de Jara Goiris é o PLRA e sua participação opositora a Stroessner; entretanto, quando analisa os resultados eleitorais, podemos considerar que o autor aborda de forma "indireta" o posicionamento político dos setores populares, por exemplo, nas eleições municipais de 1991, quando o coloradismo perdeu força. Mesmo desempenhando uma visão etapista da democracia paraguaia, os estudos de Jara Goiris são interessantes, pois ajudam a entender melhor como se estruturou o sistema democrático no país e, de forma bem tímida, apresenta as perspectivas desse modelo político.

Lançado em 2003, o livro El último supremo: la crónica de Alfredo Stroessner, do jornalista paraguaio Bernardo Neri Farina, tem como objetivo compreender o passado stronista e, mais do que isso, entender a sociedade paraguaia durante boa parte do século XX.

Tendo início na década de 1910, o livro apresenta toda a instabilidade política do Paraguai ao abordar os inúmeros golpes de Estado, tanto que "llegaban esos cambios durante un largo tramo de nuestra historia, que muchas veces la gente del pueblo ni se enteraba de que hacía dias había un nuevo primer mandatario en el Palacio de López" (FARINA, 2003, p. 23). Essa instabilidade prévia com a ditadura stronista é destacada pelo autor para dar um panorama do

\section{GANPHLAC}

Revista Eletrônica da ANPHLAC, ISSN 1679-1061, Nº. 18, p. 23-56, jan./jul. 2015.

http://revista.anphlac.org.br/ 
caos político que o país vivia no começo do século $\mathrm{XX}$ e apresentar que, após ascensão do general Stroessner, as estruturas políticas do país se estabilizaram.

Logo na introdução, Neri Farina aborda os aspectos do governo de Stroessner, afirmando que:

Nada se le escapaba. Ni tan siquiera aspectos más íntimos de la vida privada de las personas. Él lo sabía todo y podía obrar en consecuencia. [...]. Entonces se entró en el inmovilismo proprio de toda dictadura. La gente comenzó a perder capacidad ejecutiva, posibilidad de iniciativa propia y hasta de criterio personal [grifo meu]. Se acrecentó la masa en desmedro de la ciudadanía y a la par que Stroessner aumentaba su ascendencia dictatorial, los paraguayos mediocrizaban su propia voluntad individual [grifo meu]. [...]. Así se fue perdiendo el sentido se fue perdiendo el sentido crítico y se desmontó el resto del criterio político de la masa. Era mejor rendirse a la voluntad de Stroessner porque así las cosas irían mejor [grifo meu], se construiría un país rico y progresista, habría paz, no se sucederían ya las tan destructivas revoluciones y golpes de Estado; las madres ya no llorarían a sus hijos muertos en aventuras proporcionadas por políticos desquiciados. [...]. Y el miedo también se volvió rutina. Como el silencio, la delación, la traición al compañero para congraciarse con el mandón [grifo meu]. [...]. Todo el peso de la historia de sometimientos se abatió sobre el Paraguay. [...]. Para ser libres de la pobreza, había que someterse a Stroessner. Para ser libres había que someterse [grifo meu]. No quedaba otro camino más que el sometimiento (FARINA, 2003, p. 2627).

Essa visão é muito complicada, pois submeter-se a algo não significa aceitá-lo. É importante também frisar que Neri Farina reproduz o discurso stronista e de outros autores conservadores. Quando analisa o período de repressão e terror durante o governo de Stroessner, Neri Farina afirma que a ditadura stronista assassinou poucos indivíduos, frente aos outros regimes autoritários da região:

Es imposible dar ni tan siquiera una cifra aproximada y corroborante de la cantidad de muertos que dejó el régimen stronista. Se tiene certeza de algunos [...], pero en general, los mayoría de los analistas expresan que en los casi 35 años en el poder, al gobierno de Alfredo Stroessner se le podrían atribuir entre 200 y 300 muertos. Teniendo en cuenta la duración del mandato de Stroessner, son cifras "escuálidas" si se las comparan con las de Argentina y Chile. [...]. Sin embargo, hay que tener en cuenta que Stroessner no tuvo frente a sí una oposición realmente organizada que recurriera a las armas con la estructura suficiente para vencerlo. Entonces, no necesitó del genocídio (FARINA, 2003, p. 188).

Comparar a repressão, a violação aos direitos humanos e os assassinatos proporcionados por organismos estatais entre distintas ditaduras da região é uma atitude questionável, pois, a partir de uma visão quantitativa, "suaviza" o terror da ditadura stronista. Afirmar que um

\section{GANPHLAC}

Revista Eletrônica da ANPHLAC, ISSN 1679-1061, Nº. 18, p. 23-56, jan./jul. 2015.

http://revista.anphlac.org.br/ 
governo autoritário foi mais "brando" e o outro menos é uma anamorfose de determinados fatos históricos. Além disso, o autor desconsidera outros aspectos como a tortura, as prisões, etc. Essa "suavidade" explicaria também o suposto apoio da população ao ditador?

O livro de Neri Farina é um dos mais populares sobre o período em questão, já que o jornalista é muito conhecido na sociedade paraguaia. Com uma linguagem jornalística de fácil compreensão e uma circulação expressiva, El último supremo contribui com os estudos sobre a época stronista por sua pesquisa de fôlego e por abranger um tema tão amplo e complexo.

Publicado nos Estados Unidos em 2007 e traduzido do inglês para o espanhol em 2011, o livro El Régimen de Stroessner y la resistencia indígena, do historiador estadunidense René D. Harder Horst, tem como objetivo central reconhecer o protagonismo dos povos indígenas durante a ditadura stronista, comprovando que esses grupos tiveram uma participação política expressiva durante a última ditadura paraguaia. De acordo com Horst, os indígenas tiveram participação ativa nos acontecimentos históricos, ao utilizar politicamente tanto as missões religiosas quanto a Igreja Católica, ou até mesmo as instituições estatais, para benefícios próprios, ou seja, para reivindicar seus direitos e suas terras, expropriadas por fazendeiros, camponeses e funcionários públicos.

Para o autor, ao longo:

[...] del resto de su prolongado mandato, el dictador hizo uso de la represión y otros métodos para asegurar un estable clima político, una población sumisa y un proletariado sometido. [...]. La represión inicial de líderes obreros, sin embargo, demostró que las técnicas políticas de mano dura no garantizan la conformidad popular pasiva por mucho tiempo, particularmente entre las clases populares que no se beneficiaban de la corrupción estatal (HORST, 2011, p. 51).

Horst demonstra aqui que, mesmo com as repressões durante a primeira década do governo de Stroessner, os setores populares não se tornaram submissos e passivos ao regime, contrariando a visão de muitos autores, como Lewis e Neri Farina. Nesse período, são intensificadas as políticas de "integração" dos indígenas, porém, apesar dos esforços "estatales para excluir a los pueblos indígenas del desarrollo económico, una serie de causas los había movilizado lo suficiente como para desacreditar las políticas sociales del dictador (HORST, 2011, p. 55)".

\section{GANPHLAC}

Revista Eletrônica da ANPHLAC, ISSN 1679-1061, Nº. 18, p. 23-56, jan./jul. 2015.

http://revista.anphlac.org.br/ 
Essas "políticas de integração", desenvolvidas pelo regime, tinham a função de excluir os indígenas economicamente, ao introduzi-los em um sistema de trabalho distinto de sua realidade em questão. Mesmo com os planos de integração, que visavam a excluir os nativos e/ou assimilálos à sociedade, os povos indígenas se mobilizaram para lutar contra as estratégias do regime. Isso fica muito claro quando Horst apresenta um panorama sobre as atuações políticas dos nativos, em que afirma que os:

[...] pueblos indígenas del Paraguay resistieron en forma creativa los intentos del régimen de incorporarlos a la sociedad paraguaya. [...] A lo largo de la campiña, los grupos nativos se unieron y batallaron en pos del logro de la propiedad legal de las tierras, preservar sus bosques y recuperar sus territorios ancestrales. Mediante la amplia organización de comunidades indígenas defendieron la autosuficiencia económica que habían logrado conservar mediante la producción de subsistencia. Los pueblos indígenas prosperaron a través del respaldo, tanto católico como protestante, en atraer el apoyo popular a sus reclamos de aseguramiento de tierras. En algunos casos, estos movimientos indígenas tuvieron considerable éxito. Mediante protestas generalizadas en contra de los programas estatales, los líderes indígenas presentaban al país un plan político diferente. Los grupos nativos reclamaron colectivamente tolerancia para el pluralismo étnico, trato igualitario para minorías y respecto nacional hacia modos de vida diferentes [grifo meu]. [...]. Las comunidades indígenas prontamente aprendieron a emplear hábil y conscientemente su identidad étnica en procura de ventajas políticoeconómicas. A medida que se acrecentaba la protesta civil contra el régimen durante la década de los ochenta, la cooperación entre los grupos nativos y las misiones contribuyó a desestabilizar la posición de Stroessner. La movilización indígena finalmente contribuyó a la decadencia de la dictadura [grifo meu] (HORST, 2011, p. 193-194).

Para Horst, os povos indígenas resistiram às agressões de órgãos estatais e de missionários religiosos, às tentativas de políticas governamentais de integração e às expropriações de terras realizadas por militares, fazendeiros, industriais, camponeses, de missões religiosas e de funcionários públicos. Com mobilização, união em assembleias indígenas, idas até a capital para protestar, utilização da imprensa, organização de protestos contra o governo, os povos indígenas reivindicaram suas terras, seus recursos naturais e, mais do que isso, um tratamento igualitário frente à sociedade paraguaia, ao apresentar um novo plano político, reforçar suas identidades étnicas e contribuir para a crise do governo stronista.

Apesar de Stroessner considerar os indígenas:

[...] ignorantes, ineptos y mal informados [...], los nativos de hecho activamente desafiaban los conceptos tradicionales nacionalistas y el concepto mismo de NaciónEstado [grifo meu]. Al plantear sus objetivos a la vanguardia de la política nacional, los

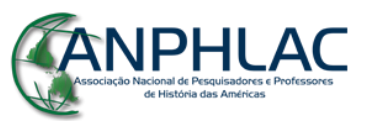

Revista Eletrônica da ANPHLAC, ISSN 1679-1061, №. 18, p. 23-56, jan./jul. 2015.

http://revista.anphlac.org.br/ 
grupos indígenas demostraron a Paraguay que tendría que reconocer sus derechos y creciente influencia. En contra de toda expectativa, las movilizaciones de los grupos indígenas ayudaron a contribuir al colapso de la larga dictadura de Stroessner y su hegemonía (HORST, 2011, p. 341).

Horst não pretende "dar voz" aos indígenas nem "conscientizá-los" a partir de uma posição paternalista da história, mas os considera atores políticos, sociais e, sobretudo, históricos, que contribuíram para a queda de um governo autoritário, e, a partir de várias lutas, muitos grupos conseguiram suas propriedades. Entretanto, o principal êxito teria sido a criação de uma identidade étnica indígena, frente à união dos nativos em assembleias. Além disso, a inclusão de artigos em defesa dos indígenas na Constituição de 1992 teria sido outra vitória notória e expressiva.

É importante ressaltar que muitos nativos contribuíram com o regime, como bem mostra o autor em seu livro. Entretanto, a grande relevância desse estudo é destacar as resistências indígenas e como esses grupos utilizaram as ONGs, os órgãos indigenistas estatais e sociais e as missões religiosas (protestantes e católicas) em benefício próprio, a fim de obterem seus objetivos políticos e econômicos. Para Horst, diferentemente dos outros autores trabalhados nesse artigo, os setores populares, a partir da figura dos indígenas, não foram passivos nem omissos diante do regime autoritário do general Stroessner e se mobilizaram e organizaram, em grande parte de forma independente, para lutar contra o governo. Assim, são representados como grupos que tiveram uma ação política e histórica destacável.

Em 2008, o Paraguai viveu um momento histórico em sua política: a eleição de Fernando Lugo à presidência. Foi nesse mesmo ano que foi lançado o livro Paraguay: ciclos adversos y cultura política, do politólogo paraguaio Fábio Anibal Jara Goiris, já citado anteriormente. O objetivo do autor nesse livro é estudar as mudanças políticas, sociais, econômicas e culturais da sociedade paraguaia, desde o período colonial até o governo de Stroessner, e sua cultura política autoritária. Uma das principais consequências dessa cultura política autoritária seria a existência de um eleitor conservador:

Es como si el elector paraguayo no quisiera comprometerse con los demás y tampoco con las instituciones políticas. [...]. Conoce su derecho a la participación pero permanece ensimismado. Se manifiesta a veces pero le falta práctica. Reacciona políticamente pero no tiene dirección. [...] La política, para este elector, se desarrollaría

\section{GANPHLAC}

Revista Eletrônica da ANPHLAC, ISSN 1679-1061, Nº. 18, p. 23-56, jan./jul. 2015.

http://revista.anphlac.org.br/ 
solamente por acción de otros, es decir, por actividad exclusiva de políticos y autoridades nacionales. [...]. Todo indica que el elector conservador prefiere el silencio y la resignación o en la mayoría de los casos se encierra en un universo de alienación, de enajenación mental, creado principalmente por efecto perverso del discurso continuista y anestesiante del Partido Colorado [grifo meu] (GOIRIS, 2008, p. 238239).

Entretanto, o que o autor considera participação política? Seria o fato de os populares votarem? É importante destacar que as eleições durante o stronismo eram fraudulentas. Diante disso, votando em Stroessner os setores populares estariam contribuindo para uma ditadura e se tornando conservadores, ou estariam jogando com o sistema político no qual estavam inseridos? Esse "jogo" diz respeito às atitudes desses grupos, que não se manifestavam abertamente contra o governo.

Há, nessa análise, a perspectiva de uma coisificação do Paraguai, ao observar a história desse país de forma determinista e anacrônica, acreditando em um eterno retorno de suas estruturas políticas e sociais e que os setores populares, frente a essa realidade, não agiriam politicamente contra esses governos, pois estariam impossibilitados para tal.

Jara Goiris, em sua obra, preocupa-se excessivamente em introduzir as teorias e os conceitos herdados de outros autores ao caso paraguaio e se esquece de detectar as singularidades, as rupturas e as continuidades da sociedade na época do stronismo. Os referenciais teórico-metodológicos servem como instrumentos que "guiam" as análises para um caminho específico. Diferentemente da forma como utiliza o autor, que expõe um universo de conceitos e teorias sem os aplicar corretamente, tornando-se escravos deles.

O último livro analisado nesse artigo foi publicado em 2012, alguns meses após o golpe parlamentar contra o presidente Fernando Lugo, e escrito pela socióloga argentina Lorena Soler. Paraguay, la Larga Invención del Golpe: el stronismo y el orden político paraguayo propõe investigar o governo stronista a partir da análise de algumas instituições estatais e políticas, tidas como peças centrais para a reprodução do processo de mudanças e das estruturas políticoeconômicas e responsáveis para o êxito da modernização conservadora organizada por uma revolução "desde cima".

A autora também procura entender como o discurso do resgate do passado, mediante um clima antiliberal, nacional e militar, esteve presente no cenário político desenvolvido por

\section{GANPHLAC}

Revista Eletrônica da ANPHLAC, ISSN 1679-1061, Nº. 18, p. 23-56, jan./jul. 2015.

http://revista.anphlac.org.br/ 
Stroessner que, a todo momento, se colocava como um herdeiro e sucessor das "famílias fundadoras" do país, como uma forma de se legitimar. ${ }^{9}$ Além disso, Soler busca compreender o processo de mudanças do stronismo, analisando um novo padrão de acumulação que propôs um marco constitucional e uma nova relação entre o Estado e a sociedade, em que se evidencia uma nova forma de organização social.

A proposta central desenvolvida pela autora é analisar o governo de Stroessner em seu conjunto - tendo como prioridade os aspectos sócio-históricos de longa duração - que configurou um regime de estruturas novas que buscava fontes de legitimidade de representações políticas do passado e do período, com o propósito de garantir raízes populares. Além disso, o governo proporcionou um processo de mudança a partir de uma modernização conservadora, ao recriar uma estabilidade política e reivindicar um princípio de legitimidade, cravado nas tradições nacionais, e se apropriar de identidades históricas nacionais, utilizando em seu discurso figuras de heróis e de momentos do passado (SOLER, 2012, p.167-170).

Entretanto, como os setores populares são representados na obra em questão? A autora, ao analisar as mudanças políticas e econômicas após o golpe de Estado que pôs fim a quase 35 anos do governo de Stroessner, afirma que esse:

[...] proceso estuvo acompañado por fragmentarias pero evidentes manifestaciones y movilizaciones de la sociedad civil, en un contexto de democratización regional y de una nueva política exterior impulsada por Estados Unidos en la región. [...]. A diferencia de las producciones marcadas por la agenda politológica de los años ochenta, que insistieron con los argumentos acerca de la complicidad de la sociedad civil y miraron con exclusividad el sistema político, sería prudente recordar el rol de aquellos actores sustantivos del proceso [...]. En efecto, si se mira más allá del estricto derrocamiento de Alfredo Stroessner en 1989, el fin de ciclo político ya se hacía evidente con el conflicto político que desde los inicios de la década del ochenta se manifestó a través de las huelgas sindicales, la presencia estudiantil, un rol activo de las iglesias y la toma de tierras por parte de los movimiento campesino, que pese a las

\footnotetext{
${ }^{9}$ O uso político dos governos de José Garcia Rodríguez de Francia (1814-1840), de Carlos Antonio López (18441862) e de Francisco Solano López (1862-1870), juntamente com suas figuras históricas, foi utilizado tanto por governos liberais quanto por governos colorados durante todo o século XX. Além disso, tanto liberais como esquerdistas quanto nacionalistas de direita analisaram e criticaram ou reutilizaram as noções ideológicas dos regimes de Francia e dos López. Esse é um dos eixos do livro do pesquisador paraguaio Guido Rodríguez Alcalá, Ideología autoritaria, lançado em 1987, ainda quando a ditadura de Stroessner era vigente. Tanto Higínio Morínigo, como Natalicio González e Alfredo Stroessner afirmaram, em seus discursos, que eram autênticos sucessores de Francia e dos López. Lorena Soler, quando aborda a questão o uso político desse passado durante o stronismo, possui como parâmetro a obra de Rodríguez Alcalá.
}

\section{GANPHLAC}

Revista Eletrônica da ANPHLAC, ISSN 1679-1061, №. 18, p. 23-56, jan./jul. 2015.

http://revista.anphlac.org.br/ 
restricciones políticas, ascendía a "28.000 campesinos asociados a alguna organización nacional" [grifo meu] [...]. Esta situación preconfiguraría un panorama que ilustraba a las claras un régimen en crisis, en tanto había perdido los basamentos principales de su legitimidad política: el orden social como pilar de su crecimiento económico [grifo meu]. Finalmente, la pérdida del control del Estado y del Partido Colorado, que otrora dotaban de sentidos a los vínculos políticos, fue la expresión última de un modo de acumulación económica: "la desestatización de la sociedad se (interpelaba) como una demanda democratizante de la sociedad" [grifo meu] [...] (SOLER, 2012, p. 137-139).

Aqui, a autora critica os estudos acadêmicos que apresentam a sociedade civil como cúmplice das estruturas autoritárias do regime stronista e mostra a participação política dos setores populares durante a década de 1980, por meio de manifestações e greves, como um processo democratizante da sociedade.

Sobre a participação dos camponeses no processo de mobilizações políticas no final do stronismo, Soler afirma que o:

[...] debilitamiento de los mercados de la Argentina y Brasil y el descenso de la cotización externa del algodón y la soja agudizaron el panorama económico. Como consecuencia, [...] fueron los movimientos campesinos quienes protagonizaron las acciones colectivas más importantes en respuesta a la crisis [grifo meu], registrando 18 ocupaciones en la que se movilizaron 5.271 familias. Lo novedoso es que los mismos provenían no solo del campo, sino especialmente de las capas medias semi asalariadas. Eran ex obreros del emprendimiento hidroeléctrico de Itaipú y obras conexas que tomaron las fracciones de tierras aptas en la región de la represa. Si bien las demandas, se limitaban al acceso a la tierra y no planteaban cambios institucionales (aunque se organizaran mediante mecanismos de democracia directa), mostraban a las claras el cierre de una etapa donde el crecimiento económico pudo resultar disciplinador (SOLER, 2012, p. 139).

Soler analisa a crise da década de 1980, a exemplo de outros autores, não a partir de um viés econômico, mas sim de uma perspectiva político-ideológica, pois seria uma crise do discurso stronista como "herdeiro dos pais fundadores". Podemos perceber em seu estudo que, antes mesmo de 1980, o governo utilizava mecanismos para conter demandas da sociedade, como, por exemplo, a "fachada democrática" e o "voto das mulheres". Essas medidas não impediram as manifestações políticas dos setores populares, que protestaram contra a crise econômica e, intrinsicamente, contra o sistema político, do qual faziam parte.

Os estudos apresentados nesse trabalho são importantes, pois muitos são pesquisas acadêmicas e, como tal, tomam cuidados específicos, delimitam melhor os objetos de estudo e

\section{GANPHLAC}

Revista Eletrônica da ANPHLAC, ISSN 1679-1061, Nº. 18, p. 23-56, jan./jul. 2015.

http://revista.anphlac.org.br/ 
dialogam com um enquadramento teórico-metodológico bem definido. Ainda assim, nessas obras os autores continuam, em grande parte, a reproduzir a ideia de uma população estigmatizada pelo medo e que só reagiu à ditadura em meados dos anos 1980, quando esta se encontrava em uma profunda crise político-econômica. Livros como o de Horst e, em certa medida, de Soler vão na contramão dos outros estudos, destacando uma sociedade mais complexa e, no caso de Horst, a atuação política significativa de um grupo social, como os povos indígenas do interior.

O ano de 2012 foi marcado pelo maior abalo sofrido pelas recentes estruturas democráticas que o Paraguai vinha construindo: o golpe parlamentar contra o presidente Fernando Lugo. Esse período foi marcado por manifestações, movimentos sociais e iniciativas populares, político-partidárias e intelectuais que questionaram a decisão do Parlamento quanto à destituição de Lugo e a não volta de uma ditadura no país. A memória sobre os tempos do regime stronista foi rediscutida e as feridas reabertas, ao questionar as falhas existentes na democracia política paraguaia que, após a oscilação sofrida com o "Março paraguaio", em 1999, e reafirmação de sua estrutura, entrou novamente em crise.

\section{Reflexões finais: Perspectivas e dilemas da historiografia sobre o stronismo}

Encerramos esse artigo com algumas reflexões finais, sobretudo no que se refere às perspectivas e aos dilemas das produções historiográficas sobre o período do governo do general Alfredo Stroessner no Paraguai. Em grande parte dos estudos (NERI FARINA, LEWIS, JARA GOIRIS), os autores acreditam que o Partido Colorado era uma agremiação de massas e que teve um expressivo respaldo popular. Esses livros também consideram que a Igreja Católica e os partidos oposicionistas ao regime foram instituições que conscientizaram o povo paraguaio de que precisaria ser organizado e instruído politicamente, evidenciando-se, assim, a imagem de uma sociedade desarticulada, engessada politicamente, passiva e dominada pelo temor.

Além disso, alguns desses trabalhos (NERI FARINA, LEWIS, JARA GOIRIS) contêm um erro repetido constantemente: ao analisar a ditadura stronista, esses estudos recorrem a uma volta às origens, remetendo-se ao século XIX para explicar questões existentes na sociedade

\section{CANPHLAC}

Revista Eletrônica da ANPHLAC, ISSN 1679-1061, Nº. 18, p. 23-56, jan./jul. 2015.

http://revista.anphlac.org.br/ 
paraguaia durante o governo de Stroessner. Há, nesse ponto, o que o historiador francês Marc Bloch (2001, p. 57) chama de "ídolo das origens", pois "as origens são um começo que explica"; pior que isso, "que basta para explicar. Aí mora a ambiguidade; aí mora o perigo". Além desse risco, há outro fator que explicaria esse "mito de origem": o desconhecimento da história paraguaia, vista como outra realidade histórica por esses autores.

Apesar de alguns estudos (HORST, BOCCIA PAZ, GONZÁLEZ e PALAU) considerarem os setores populares como atores políticos expressivos e que se mobilizaram mesmo antes da crise do governo de Stroessner, há nesses estudos a ausência de resistência da população no cotidiano. As resistências dos setores populares a partir do viés da história do cotidiano seriam interessantes, pois em um país marcado por um sistema repressivo que desarticulava e controlava o espaço público, as ações do período, assim como as memórias sobre elas, recairiam sobre o âmbito do cotidiano/privado. $\mathrm{Na}$ "ausência" de movimentos políticosociais "expressivos", a legitimidade dessas memórias sobre o passado stronista incidiria na espera do pessoal e/ou privado.

\section{GANPHLAC}

Revista Eletrônica da ANPHLAC, ISSN 1679-1061, Nº. 18, p. 23-56, jan./jul. 2015.

http://revista.anphlac.org.br/ 


\section{Referências bibliográficas}

ALCALÁ, Guido Rodríguez. Ideologia Autoritária. Asunción: Servilibro, 2007.

ARDITI, Benjamin. Adíos a Stroessner. La Reconstrucción de la política en el Paraguay. Asunción: Centro de Documentación y Estudios (CDE), 1992.

BLOCH, Marc. Apologia da história ou o ofício do historiador. Tradução: André Telles. Rio de Janeiro: Zahar, 2001.

BOCCIA PAZ, Alfredo; GONZÁLEZ, Myrian; PALAU, Rosa. Es mi informe: los archivos secretos de la policía de Stroessner. Asunción: Servilibro, 2006.

CHARTIER, Roger. A história cultural: entre práticas e representações. Tradução: Maria Manuela Galhardo. Lisboa: Difel; Rio de Janeiro: Bertrand Brasil, 1990.

CHIAVENATO, Julio José. Stroessner: retrato de uma ditadura. São Paulo: Editora Brasiliense, 1980.

DECCA. Edgar Salvadori de. O silêncio dos vencidos. São Paulo: Brasiliense, 2004.

FARINA, Bernardo Neri. El Último Supremo: la crónica de Alfredo Stroessner. Asunción: El Lector, 2003.

GOIRIS, Fábio Anibal Jara. Autoritarismo e democracia no Paraguai contemporâneo. Curitiba PR: Editora da Universidade Federal do Paraná, 2000.

2004.

. Paraguay: ciclos adversos y cultura política. Asunción, Paraguay: Servi Libro,

HORST, René D. Harder. El régimen de Stroessner y la resistencia indígena. Asunción: Centro de Estudios Antropológicos de la Universidad Católica (CEADUC), 2011.

LEWIS. Paul H. Paraguay bajo Stroessner. México: FCE, 1986.

MASI, Fernando. Stroessner: la extinción de un modelo político en Paraguay. Asunción: Intercontinental Editora, 1989.

MENEZES, Alfredo da Mota. A herança de Stroessner: Brasil-Paraguai, 1955-1980. Campinas: Papirus, 1987.

\section{GANPHLAC}

Revista Eletrônica da ANPHLAC, ISSN 1679-1061, №. 18, p. 23-56, jan./jul. 2015.

http://revista.anphlac.org.br/ 
ROMERO, L. A. Los sectores populares urbanos como sujetos históricos. In:

GUTIÉRREZ, L. H. Sectores populares, cultura y política: Buenos Aires en la entreguerra. Buenos Aires: Siglo XXI, 2007.

SOLER, Lorena. Paraguay, la larga invención del golpe: el stronismo y el orden político paraguayo. Buenos Aires: Imago Mundi, 2012.

\section{QANPHLAC}

Revista Eletrônica da ANPHLAC, ISSN 1679-1061, №. 18, p. 23-56, jan./jul. 2015.

http://revista.anphlac.org.br/ 